\title{
A Longitudinal analysis of the Porterian paradigm utilization in Brazil
}

\author{
Simone Sehnem ${ }^{\dagger}$ \\ Oeste de Santa Catarina Universiy - UNOESC \\ Fábio Lazzarotti ${ }^{\Omega}$ \\ Oeste de Santa Catarina Universiy - UNOESC \\ Rodrigo Bandeira-de-Mello ${ }^{¥}$ \\ Getulio Vargas Foundation - FGV/EAESP
}

\begin{abstract}
SUMMARY: The purpose of this article is to investigate to what extent Michael Porter;s ideas keep attracting the interest of Brazilian researchers vis-à-vis other possibilities. In this research, we conceptualize Porter's paradigm by the the following elements: strategic groups, generic strategies, model of the five forces and value chain. Weanalyzed conferece communications to EnANPAD's, from 1998 to 2008, and to 3Es, from 2003to 2007. The results indicate a decline in the use of the porterian paradigm as the main axis of research in strategy. The generic strategies and the model of five forces are the elements of Porter's paradigm most employed, while the concepts of strategic groups and value chain are the ones that received less attention by researchers. The analysis of methodology and purpose of comunications indicates that the "porterian life" in Brazil was characterized by the acritical use of its concepts in order to describe the reality of the strategy in Brazil. There are no evidences of consistent and systematic attempts to test or adapt the porterian paradigm for the Brazilian context. And results indicate no evidences that this trend will be reversed.
\end{abstract}

Keywords: Porter model, strategy in Brazil, bibliometric study, longitudinal analysis.

Corresponding authors*:



Editor's note: This paper was accepted by Antonio Lopo Martinez 


\section{INTRODUCTION}

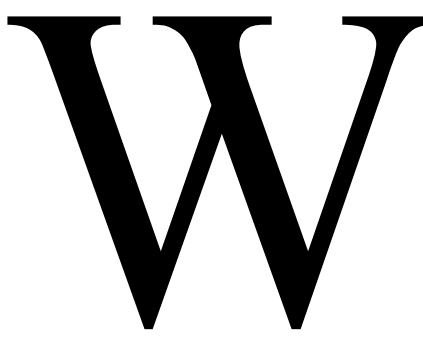

hen the subject is Strategy, one of the most featured authors is Michael Porter, who introduced in the early 1980s typologies and models that apply both to advisory works and academic studies. In Brazil, the predominance of Porter was evident. According to Bignetti and Paiva (2002, p.116), Porter is dominant and recurrently mentioned by Brazilian researches in the articles presented in the ANPAD - EnANPAD Meeting: Porter model of competitive analysis is employed, for example, for the identification of environmental forces that influence the competition of companies and for the analysis of the competitiveness of several sized companies and from the most diversified industrial and service sectors.

References to Porter are also made in the discussion of the value chain, in the study or definition positioning strategies and in the analysis of industrial clusters. A similar work was developed by Bertero, Vasconcelos and Binder (2003), concerning the Brazilian scientific production in Strategy, in the period from 1991 to 2002.

The authors established as objective to present a systematic surveying and a critical assessment of the scientific production of the Business Strategy in the period from 1991 to 2002. The results suggest that in the decade analyzed, the strategy as area of knowledge acquired autonomy in the Administration field in Brazil, having its owned space in meetings and academic publications. There is predomination of strategy conception as positioning, as one of the converging factors that help to explain such phenomenon consists in the unarguable impact of Michael Porter as the author that influenced the area from 1980.

The present article joins the previous studies contribution in two main points: first, while the article of Bertero, Vasconcelos and Binder (2003) focuses on the scientific production of the business strategy, this article focus on the longitudinal analysis of the utilization of ideas from Porter in the researches in Strategy.

Given the predominance of such paradigm, according to the results of the previous surveyings, it is important to analyze in details how this paradigm was used. It is also used, in addition to the criteria regarding the content and methodology adopted in the previous studies, an analysis of the study's purpose. This allows a more detailed analysis of the utilization of the elements from the porterian paradigm. Second, while Bertero, Vasconcelos and Binder (2003, p.05) conclude that "the criticisms do not seem to shake the appeal that Porter's approach was able to conquer the strategic management since its appearance in the 1980s”, 
using data until 2002, this article updates the analysis to explore up to which point this “appeal” persists and how it occurs.

With this double contribution, of refining and updating the previous studies it is expected that the present article becomes clearer and detailed of how Porter's ideas were used by the researchers in strategy in the country. In face of that, it is analyzed the "porterian life" in Brazil, or the employment of the porterian paradigm in the Brazilian researches. It is investigated how and to what extent the ideas of Michael Porter were, or still are, interesting vis-à-vis concurrent ideas. The objective is to analyze the use history of the porterian elements in Brazil, how and with what purpose they are employed in researches.

Porter's paradigm is investigated from its main elements: strategic groups, generic strategies, the model of the five forces and the value chain. It was performed a bibliometric analysis in a communications of article sampling in the Encontro de Estudos em Estratégia 3Es (Meeting of Studies in Strategy) of the Associação Nacional de Pós-Graduação $e$ Pesquisa em Administração - ANPAD (National Association of Post-Graduation and Research in Administration) and in EnANPAD, from 1998 to 2008. The analysis of the "porterian life", by revealing how the elements of Porter are used in researches in Brazil, indicates that up to which point the scientific knowledge in Strategy, specifically surrounding Porter's paradigm, is accrued, renewed and created. The combined analysis of the content, of the methodology and of the purpose in which the porterian paradigm was employed indicated if the scientific research in Strategy is contribution to avoid the merely bookish reproduction and learning of such paradigm.

\section{THEORETICAL BASIS}

This section introduces the elements of the porterian paradigm: the model of strategic groups and of the five forces, the typology of the generic strategies and the value chain. Those are also the same paradigms widely used in scientific publications, but that, in the study now described were operationalized with the intention of analyzing the "porterian life" in Brazil.

There is no intention here to review them in details, but to present an overview of how they are interrelated. It was in the seminal work of Caves and Porter (1977) that appeared the introduction of the mobility barriers concept, vital for Porter's later publications. Then he extended the SCP paradigm (Structure-Conduct-Performance) giving emphasis to the matter of conduct or of strategy, which generates the mobility barriers. .The companies strategically decide (strategic dimensions) and commit to their decisions, respecting the trade-offs. This 
discourages the imitation, creating barriers of mobility, or cognitive and structural origin that impede the imitation, i.e., the passage of a strategic group to another. Within such context, Porter presents the typology of the strategic groups for structural analysis inside the industries. According to (2004), the constitution of a strategic group goes through the identification of strategic dimensions, such as, specialization, identification of brands, channel policies, product quality, vertical integration and pricing policy. Such dimensions work as parameter in the industry, to verify which companies that present similar behavior give rise to the so called strategic group.

The companies that belong to one group, by creating mobility barriers, can take advantage of such condition, via scaled economies, organizational advantages in systems of distribution, costs, among others. Such condition helps to explain why some companies within the same industry manage to be more profitable than others. Therefore, the strategic group may be understood as a reference chart to guide the structural analysis, working as parameter between the global vision of the industry and of the company (PORTER, 1979).

What makes the distinction between the strategic groups are the differences in the decisions across the competitive dimensions, i.e., its strategic positioning (PORTER, 2004). For example, Gimenez (1998), in light of Porter (1979), defines strategic groups as companies that follow similar strategies in the combination of the four dimensions (company sizes, competitors' specialization degree, quality and price of the products and services and the proactivity degree of the competitors in the market), in the most varied ways. Porter (1980) proposed three strategies or profile of the strategic dimensions that are the product differentiation, the cost leadership and focus.

The three strategies represent approaches to assist the company to define its strategic positioning. In the context of the strategic group, they can represent general types of groups, i.e., it is possible to have in the industry a group formed by companies that operate in diversified ways and other group that presents cost leaderships. For example, in the research performed by Pinho and Silva (2001) about the performance of the pharmaceutical industry market, it is observed the configuration of five strategic groups that were systematized by authors according to the characteristics of cost strategies, of differentiation, of focus in costs and medium term.

In the early 1980s', Porter consolidated the concept of strategic groups by integrating them with the idea of conduct, in the structure, conduct, performance of Industrial Economics 
paradigm. He introduced the Five Forces model in his book Competitive Strategy, which originate from the structure of the industry and affect the conduct of business.

The author defined the five forces that guide competition in the industry: (a) threat of new entrants; (b) bargaining power of buyers; (c) the bargaining power of suppliers; (d) threat of substitute products or services; and (e) rivalry between the companies. In 1985, Porter, through the publication of his book Competitive Advantage, aimed at identifying the sources of competitive advantage, using the model of the value chain. This way, the author sought to systematically examine the activities performed by a company, as well as how they are linked or connected to the activities of other companies.

Therefore, Porter (1985) sought to describe how a company can gain a sustainable cost advantage or differentiate yourself from your competitors. Based on this assumption, the competitive strategy is now defined as the creation of a unique and valuable positioning, by setting a different set of activities - in relation to their unique content or exclusive mode of execution. In the article "What is Strategy" in 1996, Porter reiterates the question of the unique combination of activities, which means deliberately choosing a different set of activities to deliver a unique value. Something valuable, rare and can not be imitated. Therefore, Porter began to present a systemic view of competitive advantage, concluding that the competitive advantage of a company is in the complex system of its activities, in their relations (settings), and not in parts, specific strengths, core competencies or critical resources of the company (CARNEIRO, CAVALCANTI, SILVA, 1997).

According to Porter (1989), inside the value chain exist potential sources for joint actions to exchanges of value and can arise within the parts that compose it: infrastructure, technology, acquisition (purchase), production (internal logistics and operations) and market (composed of external logistics, marketing and services). Such exchanges of value can be considered primary objectives for a company entering a corporate network. Companies can concentrate on their core activities, enjoying all the benefits of flexible specialization, or share resources with similar businesses, reducing costs. According Carneiro, Cavalcanti and Silva (1997), generic strategies - cost leadership, differentiation and focus, proposed by Porter in 1980 received the acceptability both within the academic and business environment. Due the trade-off, and the complexity, and the definition irreversibility of activities system, Porter assumed that companies that perform best are those that apply one, and only one, of the three generic strategies. 
The companies intending a hybrid strategy or that failed in the search for one of three strategies were identified as stuck-in-the-midle. Therefore, Porter (1980) emphasized that companies which fall as stuck-in-the-midle employ a set of typical competetive methods and strategics of one or more of the generic strategies, however, they present a strategy that lacks consistency, achieving lower results.

The classical works published by Porter have transformed the theory, the practice and teaching of strategy in several schools in the world. His precepts, which range from the analysis of the competition complexity, based on five underlying forces, also expound on the generic strategies, namely, lower cost, differentiation and focus, responsible for structuring the strategic positioning, and even about the nations' competitive advantage (element not addressed in this article). In a recent publication, Porter reviewed its model and reaffirms the key issues presented in previous classical studies (Porter, 2008).

\section{METHODOLOGY}

In this research a bibliometric (descriptive research) and historical survey was done in the studies that used the Porter's perspectives. The considered universe covered the period between 1998 and 2008. The sample was narrowed to communications in the main conferences of ANPAD area, the EnANPAD and the 3Es. Communications to congress relevantly reflected in a research efforts in business administration in Brazil. Whereas only one of these papers is published in the journal, we opted for communications to obtain a broader sample.

It is, therefore, a longitudinal study of nature, which made use of a qualitative and quantitative approach to data handling. The initial sample consisted of papers presented at academic division Estratégia em Organizações - ESO (Organizations Strategy) (in 2001 to 2008 EnANPAD'S) or its equivalent (ORGEST - Organizations / Strategy, AE - Strategic Management and ADE - EnANPAD'S Strategic Management in 1998, 1999 and 2000, respectively). It was also contemplated in the sample the last three events of the Encontro de Estudo em Estratégia (Meeting of Study Strategy) - 3Es, 2003, 2005 and 2007. The total number of analyzed papers was 1041 articles. The screening was made from the time the word "Porter" appeared in the text. Of this total, 543 articles were found, which showed at least one occurrence of the name "Porter" in the works. Subsequently, they were classified based on the categories of analysis that operationalize the "porterian" paradigm: value chain, generic strategies, five forces and strategic groups, as defined in the previous section. 
The classification criterion was based on reading and text analysis of each of the 543 articles to determine the predominant use of the elements and analytical categories. This job classification was cross-checked by the authors to resolve inconsistencies. An initial screening showed that many articles mention one or more of the elements of Porter's paradigm only in theoretical or the introduction of work, in a shallow manner.

Other articles in order that the keyword screening was "Porter", just referenced the author's name at some time or they used to substantiate some other subject, different from "porterian” paradigm. In this sense, the final sample took into account only those articles in which the elements of the paradigm defined here were the main focus of work, considering the goals, Porter's theoretical assumptions in the theoretical basis and results and/or conclusions of each work.

The final sample was reduced to only 55 papers. Due to this criterion of analysis, the articles were reclassified in the operationalising elements of the "porterian" paradigm, also reviewing its methodology. The quantitative analysis was to identify through proportionality in relation to the universe of articles submitted to the ANPAD's events, the coefficient of papers that were published mentioning each of the elements of the "porterian” paradigm.

Regarding the methodology used by the reviewed articles, the classification adopted followed the reference proposed by Machado-da-Silva, Cunha and Amboni (1990), which consists of: Empirical Research: where the paper focuses on observation and analysis, without giving prior theoretical basis; Theorical-empirical Research: where the study presents collected data, which are then analyzed and compared with current reviewed theories; Theorical Research: the papers, once they do not present empirical data, are limited to articulation, formulation and contrapositioning of theorical concepts.

Further, we attempted to verify the purpose of the publications. In general, the scientific production has a purpose, whether is to "describe" the results of a particular study, without showing the development of a new theory, or "prescribe”, proposing models or new prescriptions and alternative forms of organizations suitability to the observed reality. Another purpose found in the publications considered essential to validate models and theories, is what is termed in this study a "test of theory". The purpose of this verification was performed by analyzing the papers’ objectives, methodology, results and conclusions. The test of theory consisted of papers which sought to test and validate the "porterian” paradigm in Brazil and those who, as a result of the test results, presented new theoretical and/or proposed 
the reformulation of some element of the paradigm of Porter. Finally, we carried out a survey the Porter's works referenced in the ANPAD's events, in order to investigate what are the relevant and frequently works referenced in Brazilian publications.

\section{RESULTS AND DISCUSSION}

About $50 \%$ of the initially cataloged papers (1041) referenced Porter at some moment. The last 3Es' event, in 2007, was the event with the largest number of submissions, with 126 articles in total, among which 65 (51.6\%) mentioned Porter. This percentage is close to that also occurred in previous editions of the same event.

Considering only the EnANPAD, the average rate increased relatively, especially in the events of 1999, 2001 and 2003, when the number of articles that mentioned Porter was 70\% higher. Still on the event EnANPAD, since 2006 there has been a decline in terms of Porter's mentions in articles, ending with the 2008 event, with $40.9 \%$ of mentions in relation to the number of articles submitted that year.

Table 1: Quantity of articles submitted to the strategy sections of ENANPAD and 3Es that mention Porter

\begin{tabular}{c|c|c|c|c}
\hline Year & Event & $\begin{array}{c}\text { Articles submitted to } \\
\text { EnANPAD and 3Es }\end{array}$ & $\begin{array}{c}\text { Articles selected with } \\
\text { mention to Porter }\end{array}$ & $\begin{array}{c}\text { Relative } \\
\text { Frequency (\%) }\end{array}$ \\
\hline 1998 & EnANPAD & 32 & 17 & 53,1 \\
\hline 1999 & EnANPAD & 30 & 22 & 73,3 \\
\hline 2000 & EnANPAD & 40 & 26 & 65,0 \\
\hline 2001 & EnANPAD & 20 & 15 & 75,0 \\
\hline 2002 & EnANPAD & 55 & 27 & 49,1 \\
\hline 2003 & EnANPAD & 49 & 35 & 71,4 \\
\hline 2003 & 3Es & 96 & 52 & 54,2 \\
\hline 2004 & EnANPAD & 52 & 34 & 50,4 \\
\hline 2005 & EnANPAD & 118 & 60 & 57,0 \\
\hline 2005 & 3Es & 100 & 57 & 40,9 \\
\hline 2006 & EnANPAD & 110 & 45 & 41,7 \\
\hline 2007 & EnANPAD & 103 & 43 & 51,6 \\
\hline 2007 & 3Es & 126 & 65 & 40,9 \\
\hline 2008 & EnANPAD & 110 & 45 & $\mathbf{5 2 , 2}$ \\
\hline
\end{tabular}

Source: EnANPADs 1998 to 2008 and 3Es 2003 to 2007

This last event and the one in 2006 present the lowest relative frequency of references to Porter of all analyzed events editions. Following, Table 1, which presents the mentioned above. In the 55 articles used in the final sample, those whose main axis of research uses some element of the "porterian" paradigm were identified 80 uses of the paradigm elements. This is possible because more than one element may have been studied in the same article. Table 2 presents the statistics per year. According the relative percentage to total elements found in the number of articles submitted in the year, we observe that the "porterian" paradigm research decreases considerably from $40 \%$ of articles submitted in 1998 to $1.8 \%$ in 
2007. However, for the percentage of use of each element taking the total number of elements found per year, we observe the prevalence of the five forces model and generic strategies.

Table 2: Predominant Porterian paradigm of the ANPAD publications

\begin{tabular}{|c|c|c|c|c|c|c|c|c|c|c|c|}
\hline \multirow[t]{3}{*}{ Year } & \multirow{3}{*}{$\begin{array}{c}\text { Articles } \\
\text { submitted to } \\
\text { EnANPAD } \\
\text { and 3Es }\end{array}$} & \multirow{2}{*}{\multicolumn{2}{|c|}{$\begin{array}{c}\text { Total of } \\
\text { elements per } \\
\text { year }\end{array}$}} & \multicolumn{8}{|c|}{ "Porterian" Paradigm Elements } \\
\hline & & & & \multicolumn{2}{|c|}{ Five forces } & \multicolumn{2}{|c|}{$\begin{array}{c}\text { Strategic } \\
\text { groups }\end{array}$} & \multicolumn{2}{|c|}{$\begin{array}{l}\text { Value } \\
\text { chain }\end{array}$} & \multicolumn{2}{|c|}{$\begin{array}{c}\text { Generic } \\
\text { strategies }\end{array}$} \\
\hline & & $\mathbf{n}$ & $\% *$ & $\mathbf{N}$ & $\% \#$ & $\mathbf{N}$ & $\% \#$ & $\mathbf{n}$ & $\% \#$ & $\mathbf{N}$ & $\% \#$ \\
\hline 1998 & 32 & 13 & 40,6 & 3 & 23,1 & 3 & 23,1 & 1 & 7,7 & 6 & 46,2 \\
\hline 1999 & 30 & 10 & 33,3 & 4 & 40,0 & 1 & 10,0 & 1 & 10,0 & 4 & 40,0 \\
\hline 2000 & 40 & 4 & 10,0 & 0 & 0,0 & 2 & 50,0 & 1 & 25,0 & 1 & 25,0 \\
\hline 2001 & 20 & 3 & 15,0 & 1 & 33,3 & 0 & 0,0 & 1 & 33,3 & 1 & 33,3 \\
\hline 2002 & 55 & 13 & 23,6 & 4 & 30,7 & 2 & 15,4 & 3 & 23,1 & 4 & 30,7 \\
\hline 2003 & 145 & 15 & 10,3 & 6 & 40,0 & 2 & 13,3 & 3 & 20,0 & 4 & 26,7 \\
\hline 2004 & 52 & 7 & 13,5 & 1 & 14,3 & 1 & 14,3 & 1 & 14,3 & 4 & 57,1 \\
\hline 2005 & 218 & 4 & 1,8 & 3 & 75,0 & 0 & 0,0 & 0 & 0,0 & 1 & 25,0 \\
\hline 2006 & 110 & 6 & 5,5 & 1 & 16,7 & 1 & 16,7 & 1 & 16,7 & 3 & 50,0 \\
\hline 2007 & 229 & 3 & 1,3 & 2 & 66,7 & 0 & 0,0 & 1 & 33,3 & 0 & 0,0 \\
\hline 2008 & 110 & 2 & 1,8 & 0 & 0,0 & 0 & 0,0 & 0 & 0,0 & 2 & 100,0 \\
\hline $\begin{array}{l}\text { TOTAL } \\
\text { GERAL }\end{array}$ & 1041 & 80 & 7,7 & 25 & 31,2 & 12 & 15,0 & 13 & 16,3 & 30 & 37,5 \\
\hline
\end{tabular}

*. Related to the total of articles submitted in the year

\#. Related to the total of elements found in the year

Source: Elaborated by the authors

The decline in the researchers' interest for studing and employing the "porterian" paradigm is evident, especially since 2004. In 2005, for example, there appear only three uses of the five forces model, while the generic strategies have been studied in only one of the publications. The other elements were not studied this year. The Chart 1 below illustrates the decline of "porterian" life in Brazil and the participation of each element in the total of the items found in years. It is also presented in Table 2 that the behavior of the "porterian" paradigm in the ANPAD's publications had as main studied element the generic strategies, with $37.5 \%$ relative share, followed by five forces with $31.2 \%$ on average (first and last layer of Chart 1).



DIAGRAM 1: THE PORTERIAN LIFE IN BRAZIL

Source: Elaborated by the authors 
At the other extreme, strategic groups and value chain were the elements that have been less studied. Starting for the historical analysis of all elements of the paradigm porteriano, you can notice that there is a downward pattern, especially since 2004.

The summit of publications that deal with the "porterian” paradigm was in 2003, the year the 3Es event started. Specifically for this event, there is an even greater reduction of the publications. Observe that the last event of 3Es in 2007 did not identify any work that has studied any of the four elements of Porter's paradigm. The Table 3 presents the classification distribution of the methodology used in the final sample articles

Table 3: Research design of the selected articles

\begin{tabular}{c|c|c}
\hline Research Approach & Number of Articles & Relative Frequency (\%) \\
\hline Qualitative research & 28 & 50,9 \\
\hline Quantitative research & 06 & 25,5 \\
\hline Both (quali-quanti studies) & 14 & 10,9 \\
\hline Theoretical Test & 07 & 12,7 \\
\hline Total & $\mathbf{5 5}$ & $\mathbf{1 0 0}$ \\
\hline
\end{tabular}

Source: Elaborated by the authors

According Tables 3 and 4, based on the performed categorization, it was noticed that the use of qualitative research still predominates in the ANPAD events. Of the 55 analyzed and selected articles, 28 articles, i.e. 50.9\% of publications, made use of qualitative research method. While the use of quantitative research had a representative variation over the analyzed period, i.e. between one and another edition of the event, and the survey design used over the 11 years in $25.5 \%$ of the studies analyzed. The use of quantitative and qualitative methodology, combining qualitative methods with quantitative or vice versa, also had a significant variation. It is observed that in six editions of the ANPAD events, this methodology was not used (in 1998, 1999, 2001, 2006, 2007 and 2008), but when considering the 11 years of analyzed events, it presented an average use in $10.9 \%$ of the publications in question.

Therefore, this is the methodology less used in the analyzed cases. In theoretical essays, however, it had not a remarkable participation, and in four editions of the ANPAD events there was only one article submission per year. In six editions no articles were found in theoretical essays category and, in 2003, only three articles fall into this category.

The decline in the theoretical essays use is noticeable, mostly from the 2004 edition, and since then, no other "porterian" paradigm analytical work using this method was submitted. Following, we present the Table 4 and Chart 2, which illustrate the above mentioned. 
Table 4: Methodology employed in the study of the Porterian paradigm

\begin{tabular}{|c|c|c|c|c|c|c|c|c|c|}
\hline \multirow[t]{3}{*}{ Year } & \multirow[t]{3}{*}{ Selected Articles } & \multicolumn{8}{|c|}{ Methodologies } \\
\hline & & \multicolumn{2}{|c|}{ Qualitative } & \multicolumn{2}{|c|}{$\begin{array}{c}\text { Quanti- } \\
\text { qualitative }\end{array}$} & \multicolumn{2}{|c|}{ Quantitative } & \multicolumn{2}{|c|}{ Theoretical test } \\
\hline & & $\mathbf{n}$ & \%* & n & \%* & $\mathbf{n}$ & $\% *$ & $\mathbf{N}$ & \%* \\
\hline 1998 & 8 & 5 & 62,5 & 0 & 0,0 & 2 & 25,0 & 1 & 12,5 \\
\hline 1999 & 7 & 4 & 57,1 & 0 & 0,0 & 2 & 28,6 & 1 & 14,3 \\
\hline 2000 & 3 & 1 & 33,3 & 1 & 33,3 & 0 & 0,0 & 1 & 33,3 \\
\hline 2001 & 1 & 1 & 100,0 & 0 & 0,0 & 0 & 0,0 & 0 & 0,0 \\
\hline 2002 & 7 & 4 & 57,1 & 1 & 14,3 & 2 & 28,6 & 0 & 0,0 \\
\hline 2003 & 12 & 4 & 33,3 & 1 & 8,3 & 4 & 33,3 & 3 & 25,0 \\
\hline 2004 & 5 & 1 & 20,0 & 2 & 40,0 & 1 & 20,0 & 1 & 20,0 \\
\hline 2005 & 3 & 2 & 66,7 & 1 & 33,3 & 0 & 0,0 & 0 & 0,0 \\
\hline 2006 & 4 & 3 & 75,0 & 0 & 0,0 & 1 & 25,0 & 0 & 0,0 \\
\hline 2007 & 3 & 3 & 100,0 & 0 & 0,0 & 0 & 0,0 & 0 & 0,0 \\
\hline 2008 & 2 & 0 & 0,0 & 0 & 0,0 & 2 & 100,0 & 0 & 0,0 \\
\hline TOTAL & 55 & 28 & 50,9 & 6 & 10,9 & 14 & 25,5 & 7 & 12,7 \\
\hline
\end{tabular}

* Percentage is related to the participation of each methodology in the total of articles selected per year Source: Elaborated by the authors



DIAGRAM 2: FREQUENCY OF METHODOLOGICAL USE IN THE SELECTED ARTICLES OF ANPAD Source: Elaborated by the authors

A quick longitudinal analysis in Chart 2 suggests that the theoretical essay was important at the beginning and middle of the period studied. The trend therefore suggests a dichotomy between qualitative and quantitative research, the first prevailing on the the-latter. Another aspect observed is that the use of a methodology seems to follow a cycle. In the case of qualitative research two peaks and three valleys are observed, the latter in 2008. In the case of quantitative research, this pattern is similar but in reverse. About the purpose of the publications, observes that the descriptive studies had a measured predominance of $69.1 \%$ in relative share, followed by theory tests with $16.3 \%$ and, finally, the prescriptive purpose with 14.6\%, as presented in Table 5 and Chart 3. The longitudinal analysis suggests a trend of increasing descriptive purpose of the work. From a joint analysis of the methodology used and the purpose of the study, we can imply that the qualitative and descriptive studies are the 
majority and the trend.The near absence of studies designed to test or adjust the Porter's elements in Brazil, or even critical theoretical studies indicate that the "porterian" paradigm was used uncritically to describe a reality, the Brazilian, considerably different from that in which it was created. And the downward trend of "porterian” life, it seems that this situation will not reverse. Unlike suggested by Bertero, Vasconcelos and Binder (2003). In addition, the uncritical nature remains when the previous studies are updated, but the charm of the researchers seems to decrease.

Table 5: Methodological classification regarding the purposes of the publications

\begin{tabular}{|c|c|c|c|c|c|c|c|}
\hline \multirow[t]{3}{*}{ Year } & \multirow[t]{3}{*}{ Selected Articles } & \multicolumn{6}{|c|}{ Purpose of the Publications } \\
\hline & & \multicolumn{2}{|c|}{ Descriptive } & \multicolumn{2}{|c|}{ Prescriptive } & \multicolumn{2}{|c|}{ Theory test } \\
\hline & & $\mathbf{n}$ & \%* & $\mathbf{n}$ & $\% *$ & $\mathbf{N}$ & \%* \\
\hline 1998 & 8 & 2 & 25,0 & 3 & 37,5 & 3 & 37,5 \\
\hline 1999 & 7 & 4 & 57,1 & 2 & 28,6 & 1 & 14,3 \\
\hline 2000 & 3 & 2 & 66,7 & 1 & 33,3 & 0 & 0,0 \\
\hline 2001 & 1 & 1 & 100,0 & 0 & 0,0 & 0 & 0,0 \\
\hline 2002 & 7 & 5 & 71,4 & 0 & 0,0 & 2 & 28,6 \\
\hline 2003 & 12 & 8 & 66,7 & 1 & 8,3 & 3 & 25,0 \\
\hline 2004 & 5 & 4 & 80,0 & 1 & 20,0 & 0 & 0,0 \\
\hline 2005 & 3 & 3 & 100,0 & 0 & 0,0 & 0 & 0,0 \\
\hline 2006 & 4 & 4 & 100,0 & 0 & 0,0 & 0 & 0,0 \\
\hline 2007 & 3 & 3 & 100,0 & 0 & 0,0 & 0 & 0,0 \\
\hline 2008 & 2 & 2 & 100,0 & 0 & 0,0 & 0 & 0,0 \\
\hline TOTAL & 55 & 38 & 69,1 & 8 & 14,6 & 9 & 16,3 \\
\hline
\end{tabular}

* Percentage is related to the participation of each purpose in the total of selected articles per year Source: Elaborated by the authors

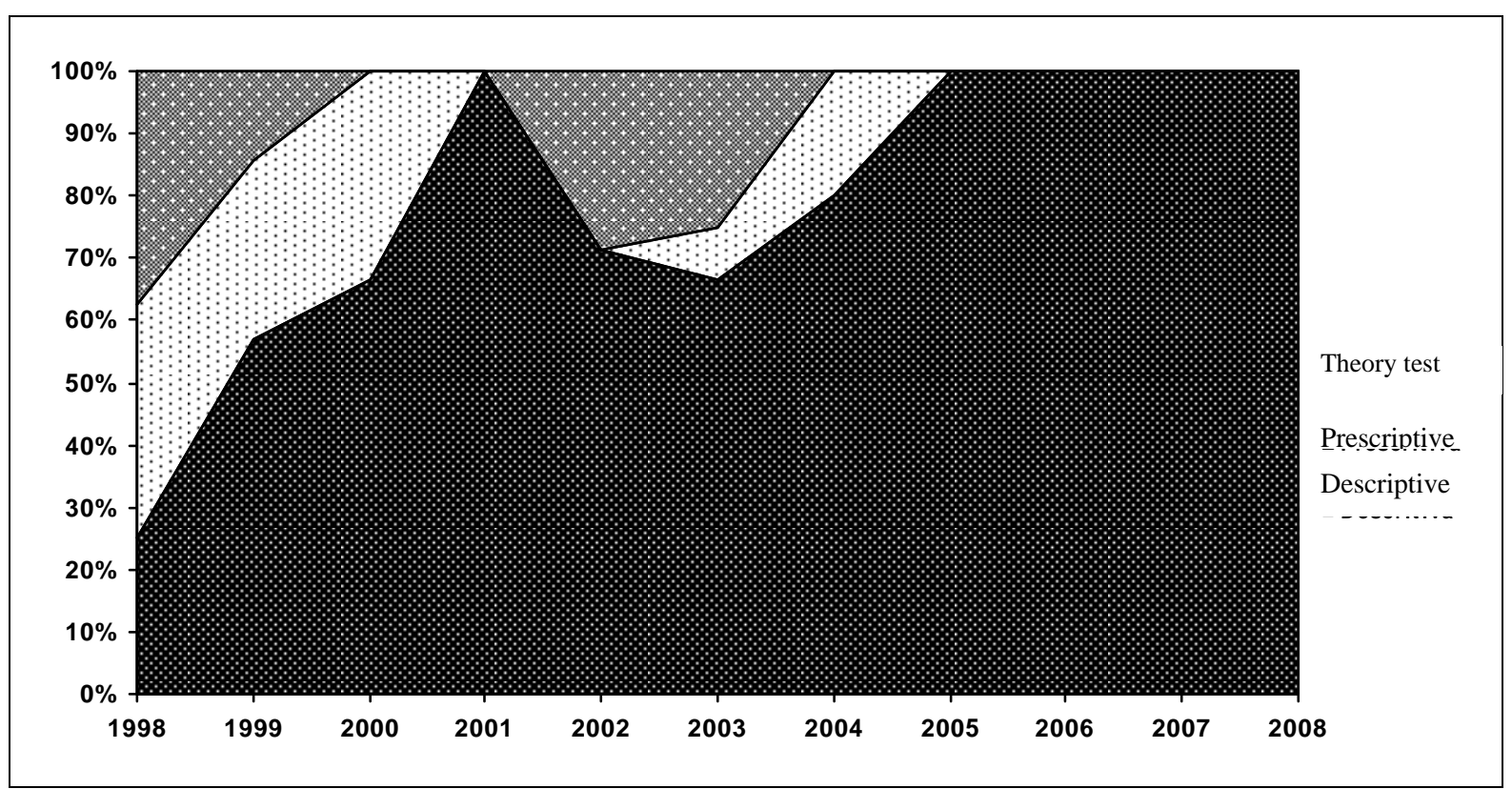

DIAGRAM 3: METHODOLOGICAL CLASSIFICATION REGARDING THE PURPOSES OF THE PUBLICATIONS

Source: Elaborated by the authors

Finally, the Table 6 was produced to show the frequency of use distribution of Porter's works in the EnANPADs scientific production from 1998 to 2008 and in the 3Es of 2003, 
2005 and 2007, especially articles which referred to Porter. In each of the 543 articles were found and cataloged all the works cited in reference to the author and then classified by type of work. For the sake of space, only the papers that had at least three referencesations in the works are described in Table 6. It can be observed that the book Estratégia competitiva: técnicas para a análise da indústria e da concorrência, with 181 referencess, i.e. $17.83 \%$ of the citations, leads the ranking of references in the analized publications.

Table 6: Frequency of Porter works referenced in the publications

\begin{tabular}{|c|c|c|c|}
\hline Referenced Works & $\begin{array}{l}\text { Absolute } \\
\text { Frequency }\end{array}$ & $\begin{array}{c}\text { Relative } \\
\text { Frequency (\%) }\end{array}$ & Work Type \\
\hline $\begin{array}{l}\text { Estratégia competitiva: técnicas para análise de indústrias e da } \\
\text { concorrência }\end{array}$ & 181 & 17,83 & Book \\
\hline Vantagem competitiva: criando e sustentando um desempenho superior & 136 & 13,40 & Book \\
\hline Competitive strategy: techniques for analyzing industries and competitors & 100 & 9,85 & Book \\
\hline Competitive advantage: creating and sustaining competitive performance & 76 & 7,49 & Book \\
\hline What is strategy? & 61 & 6,01 & Article \\
\hline Estratégia: a busca da vantagem competitiva & 59 & 5,81 & Book \\
\hline A vantagem competitiva das nações & 40 & 3,94 & Book \\
\hline Towards a dynamic theory of strategy & 34 & 3,35 & Article \\
\hline Competição: estratégias competitivas essenciais & 28 & 2,76 & Book \\
\hline Competição on competition: estratégias competitivas essenciais & 25 & 2,46 & Book \\
\hline The competitive advantage of nations & 24 & 2,36 & Book \\
\hline The contributions of industrial organization to strategic management & 18 & 1,77 & Article \\
\hline $\begin{array}{l}\text { Building the microeconomic foundation of prosperity: findings from the } \\
\text { business competitiveness index }\end{array}$ & 16 & 1,58 & Article \\
\hline Clusters and the new economics of competition & 16 & 1,58 & Article \\
\hline How competitive forces shape strategy & 14 & 1,38 & Article \\
\hline From entry barries to mobility barriers & 13 & 1,28 & Article \\
\hline How Much does industry matter, really? & 10 & 0,98 & Article \\
\hline The competitive advantage of nations & 9 & 0,89 & Article \\
\hline Competition in global industries & 9 & 0,89 & Book \\
\hline On competition & 8 & 0,79 & Book \\
\hline Como as cinco forças moldam a estratégia & 8 & 0,79 & Book chapter \\
\hline Strategy: seeking and securing competitive advantage & 7 & 0,69 & Book Chapter \\
\hline How information gives you competitive advantage & 6 & 0,59 & Article \\
\hline From competitive advantage to corporate strategy & 5 & 0,49 & Article \\
\hline O que é estratégia? & 5 & 0,49 & Book chapter \\
\hline $\begin{array}{l}\text { Location, Competition and economic development: local cluster in a } \\
\text { global economy }\end{array}$ & 4 & 0,39 & Article \\
\hline The structure within industries and companie's performance & 4 & 0,39 & Article \\
\hline Strategy and the internet & 4 & 0,39 & Article \\
\hline A vantagem competitiva das nações & 4 & 0,39 & Book chapter \\
\hline Estratégia & 3 & 0,30 & Article \\
\hline The competitive advantage of corporate philanthropy & 3 & 0,30 & Article \\
\hline Innovation: location matters & 3 & 0,30 & Article \\
\hline The role of location in competition & 3 & 0,30 & Article \\
\hline What do we know about variance in accouting profitability & 3 & 0,30 & Article \\
\hline Other referenced works (with, at least,m two references, included) & 42 & 4,14 & Others \\
\hline
\end{tabular}

Source: Elaborated by the authors 
Adding this percentage with the percentage of referenceses from the book Competitive strategy: techniques for analysing industries and competitors (which is the English version of the book that came first in the ranking), has a total of 281 referencess, which equates to more than $27 \%$ of all referencess.

Second most referenced works is the book Vantagem competitiva: criando e sustentando um desempenho superior, with 136 (13.40\%) entries, which added to the number of 76 (7.49\%) entries of the original book Competitive advantage: creating and sustaining competitive performance, has a total of 212 referencess. This makes a total index of relative frequency of $20.89 \%$. Among the articles, especially What Is Strategy?, which was mentioned 61 times or $6.01 \%$ of total references, taking first place in the ranking of most referenced Porter's articles in the analyzed events.

\section{CONCLUSIONS}

This paper analyzed the porterian life in Brazil on a sample of research conducted between 1998 and 2008 based on four main elements that operationalize the "porterian" paradigm: a model of five forces, strategic groups, the value chain and generic strategies.

Unlike the findings of previous surveys (BERTERO, VASCONCELOS, BINDER, 2003), the data show a decline in "porterian" life mostly from 2004, i.e., the declining interest of Brazilian researchers in strategy to implement some Porter's elements as the central-axis of their studies.

This may be related to the advent of new theoretical models that have emerged in contrast to theoretical assumptions recommended by Porter, for example, the RBV (Resource Based View). Concerning the elements studied, generic strategies and the model of five forces were prevalent in the works analyzed. The "porterian” elements - value chain and strategic groups - were the least frequently in the reviewed studies, which show a gap to be filled for future studies.

And although the five forces and generic strategies elements have predominated in the publications analyzed, can also represent another gap to be worked, with studies having a higher critical rigor, testing and adapting the elements of Porter's model to the Brazilian reality.

What is observed is that "porterian" life in Brazil had increased attention from researchers in the years 1998, 1999 and 2002. From 2003 to 2008, besides the decline in the 
use of Porter's paradigms, it appears that most of the work did not perform a systematic analysis of evidence as to test and validate the "porterian” theory in Brazil. It was noticed that few authors have dared to test and propose new theories from "porterian” models to better understand the influence of strategies on the performance of companies in Brazil, with the exception of Silva (1998, 1999, 2002, 2003) and Binder ( 2002, 2003). And criticism of Porter's model is common in the literature, such as Mintzberg (1988) and Faulkner and Bownan (1992).

Therefore, there is a disclosure that the themes are developed in a superficial way, because the paths inherent in the "porterian" paradigm are still little explored. It seems that Brazilian researchers prefer to use one or more elements to describe business cases to test and develop theories. Above all, it was shown that the use of the "porterian" paradigm demand higher level of reflection to be developed in future research, despite contrary trends.

The finding is supported by the research of Bertero, Vasconcelos and Binder (2003), which also indicate that, for example, prescriptive papers are practically non-existent in studies of strategies. Likewise, we see the low utilization of theory test in the articles analyzed in this study, as has been observed by the authors mentioned above in the methodology, but not on the question of the appeal.

Concerning the frequency of references in the papers of Porter's works it is possible to see that the Estratégia Competitiva, Vantagem Competitiva, also considering the original English version and the article What Is Strategy? constitute the main theoretical background used to produce scientific study. Gathering these five works of Porter, they represent over $50 \%$ of the entire body of work, referenced in 543 analyzed articles. Despite being classics, there is a lack of scientific base, which led to books, as well as publications resulting from these books, that work the models theoretically and empirically.

Regarding the limitations of this study, the analysis has been restricted to items reported in EnANPAD and 3Es and the use of descriptive statistics, although they serve the purpose of this article, it does not allow probabilistic estimates. For future studies and to verify the behavior pattern of studies on Porter in other contexts, we suggest further research, deepening in the shortcomings of this work.

You can expand the discussion on the "porterian" impact in the world, analyzing articles reported in national and international journals, in view of the employment of one or 
more of the elements of the Porter's paradigm, as well as testing and validating their theories in other countries. You can also compare if the Porter's decline is actually associated with a possible rise of other paradigms, such as the RBV. Finally, the results show that Porter went unscathed in the Brazilian academy.

There is a declining trend in their study and his life in Brazil shows that he was criticized, adapted or tested systematically, but was used primarily to describe in their assumptions a different reality from that in which the Porter's work was originate.

\section{REFERENCES}

BERTERO, C. O.; VASCONCELOS, F.C.; BINDER, M. P. Estratégia empresarial: a produção científica brasileira entre 1991 e 2002. Revista de Administração de Empresas, v.43, n.4,out./dez.2003.

BIGNETTI, L. P.; PAIVA, E. L. Ora (direis) Ouvir estrelas!: estudo das citações de autores de estratégia na produção acadêmica brasileira. Revista de Administração Contemporânea, v.6, n.1, jan/abr., 2002.

BINDER, M. P. Discussão da cadeia de valor e estratégias genéricas de Michael Porter a partir do caso Gol transportes aéreos. In: ENCONTRO ANUAL DA ASSOCIAÇÃO NACIONAL DOS PROGRAMAS DE PÓS-GRADUAÇÃO EM ADMINISTRAÇÃO (ENANPAD), 36., 2002, Salvador (BA). Anais... Salvador: Anpad, 2002.

Estratégias genéricas: posições discretas ou contínuas. In: ENCONTRO DE ESTUDOS EM ESTRATÉGIA (3Es), 1., 2003, Curitiba (PR). Anais... Curitiba: Anpad, 2003.

CARNEIRO, J. M. T.; CAVALCANTI, M. A. F. D.; SILVA, J. F. Porter revisitado: análise crítica da tipologia estratégica do mestre. Revista de Administração Contemporânea, v.1. n.3, set-dez, 1997.

CAVES, R.; PORTER, M. E. From entry barriers to mobility barriers: conjectural decisions and contrived deterrence to new competition. Quarterly Journal of Economics, v. 91, p. 241-261, 1977.

FAULKNER, D.; BOWMAN, C. Generic strategies and congruent organizational structures: some suggestions. European Management Journal, v.10, n.4, p.494-499, Dec. 1992.

GIMENEZ, Fernando Antonio Prado. Escolhas estratégicas e estilo cognitivo: um estudo com pequenas empresas. Rev. adm. contemp. [online], v. 2, n. 1, p. 27-45, 1998.

MACHADO-DA-SILVA, C. L.; CUNHA, V. C.; AMBONI, N. Organizações: o estado da arte da produção acadêmica no Brasil. In: ENCONTRO NACIONAL DA ASSOCIAÇÃO NACIONAL DE PÓS-GRADUAÇÃO E PESQUISA EM ADMINISTRAÇÃO (ENANPAD), 1990, Florianópolis (SC). Anais... Florianopolis: Anpad, 1990. 
MINTZBERG, H. Generic strategies: toward a comprehensive framework. In: SHRIVASTAVA, P. (Ed.). Advances in strategic management, Greenwich, Conn.: Jay Press, 1988. v. 5. p. 1-67.

PORTER, M. E. How competitive forces shape strategy. Harvard Business Review, v. 57, n. 2, p. 137-145, 1979.

Competitive Strategy: Techniques for Analyzing Industries and Competitors. New York, Free Press, 1980.

Competitive Advantage. New York: Free Press, 1985.

Estratégia competitiva: técnicas para análise de indústrias e da concorrência. Rio de Janeiro: Campus, 1986.

. Vantagem competitiva. 11. ed. Rio de Janeiro: Campus, 1989.

What is strategy? Harvard Business Review, p.61-78, Nov.-Dec. 1996.

Review. 2001.

The Structure within industries and companies performance. Harvard Business

The Five competitive force that shape strategy. Harvard Business Review. 2008.

Estratégia competitiva: técnicas para a análise da indústria e da concorrência. 2.ed.

Rio de Janeiro: Elsevier, 2004.

SILVA, J. F.; ALMEIDA, L. C.; ALMEIDA JUNIOR, R. B. Alianças estratégicas e a indústria financeira brasileira: impacto das estratégias colaborativas e competitivas no desempenho dos bancos comerciais, múltiplos e de investimento. In: ENCONTRO ANUAL DA ASSOCIAÇÃO NACIONAL DOS PROGRAMAS DE PÓS-GRADUAÇÃO EM ADMINISTRAÇÃO (ENANPAD), 22., 1998, Foz do Iguaçu (PR). Anais... Foz do Iguaçu, 1998. CD-ROM.

SILVA, J. F.; CAMPELO-DE-MELO, M. A. Tipologias estratégicas concorrentes: um teste empírico na indústria brasileira de seguros. In: ENCONTRO ANUAL DA ASSOCIAÇÃO NACIONAL DOS PROGRAMAS DE PÓS-GRADUAÇÃO EM ADMINISTRAÇÃO (ENANPAD), 22., 1998, Foz do Iguaçu (PR). Anais... Foz do Iguaçu, 1998. CD-ROM.

SILVA, J. F.; CARNEIRO, J.M.T.; CAVALCANTI, M. A. D. F. Impactos da privatização sobre as estratégias competitivas de empresas de petróleo: um estudo de casos. In: ENCONTRO ANUAL DA ASSOCIAÇÃO NACIONAL DOS PROGRAMAS DE PÓSGRADUAÇÃO EM ADMINISTRAÇÃ̃O (ENANPAD), 22., 1998, Foz do Iguaçu (PR). Anais... Foz do Iguaçu, 1998. CD-ROM.

SILVA, J. F.; FICHMAN, L. H. Construção de um Modelo de Predição de Insolvência Bancária Baseado na Tipologia de Porter. In: ENCONTRO ANUAL DA ASSOCIAÇÃO NACIONAL DOS PROGRAMAS DE PÓS-GRADUAÇÃO EM ADMINISTRAÇÃO (ENANPAD), 23., 1999, Foz do Iguaçu (PR). Anais... Foz do Iguaçu, 1999. CD-ROM. 
SILVA, J. F.; GOULART, P. M. Uma grande angular na análise estratégica: o modelo integrado e os impactos no desempenho. In: ENCONTRO ANUAL DA ASSOCIAÇÃO NACIONAL DOS PROGRAMAS DE PÓS-GRADUAÇÃO EM ADMINISTRAÇÃ̃O (ENANPAD), 26., 2002, Salvador (BA). Anais... Salvador: Anpad, 2002. CD-ROM.

SILVA, J. F.; BRANDT, E. A.; COSTA, L.S.V. Truelo de tipologias estratégicas na arena das franquias de fast-food no Brasil: Porter x Miles \& Snow x Mintzberg. In: ENCONTRO ANUAL DA ASSOCIAÇÃO NACIONAL DOS PROGRAMAS DE PÓS-GRADUAÇÃO EM ADMINISTRAÇÃO (ENANPAD), 27., 2003, Atibaia (SP). Anais... Atibaia: Anpad, 2003. CD-ROM. 